\title{
PROBABILITAS MODAL SHIFT MODEL ANGKUTAN UMUM DI BANDARA ADI SOEMARMO SOLO
}

\author{
Ahmad Ependi ${ }^{1}$, Email : ependi@ppi.ac.id \\ Arinda Leliana ${ }^{2}$, Email : arinda@ppi.ac.id \\ Ainun Fikria ${ }^{3}$, Email : ainun@ppi.ac.id \\ 1),2),3) Politeknik Perkeretaapian Indonesia Madiun, Indonesia
}

\begin{abstract}
ABSTRAK
Mulai 1 Desember 2019 Kereta Api Bandara Adi Soemarmo Solo beroperasi dengan rute Stasiun Solo BalapanBandara Adi Soemarmo, dengan jarak sejauh 12,9 kilometer, dan rata-rata waktu tempuh selama 20 menit. Mobilitas pergerakan dapat menyebabkan proses pemilihan moda. Pemilihan moda merupakan salah satu model yang digunakan dalam perencanaan transportasi angkutan umum. Hasil perhitungan probability perpindahan untuk variabel usia dan pekerjaan responden merupakan variabel yang berpengaruh secara signifikan. Setelah dilakukan analisis akhir dengan pengkategorian untuk tiap variabel usia dan pekerjaan, maka didapatkan kategori tiap Usia (2) yaitu usia 21-30 tahun dan usia (3) yaitu usia 31-40 tahun. Untuk kategori tiap variabel pekerjaan yang signifikan yaitu pekerjaan 1 pelajar/mahasiswa, pekerjaan 3 BUMN, dan pekerjaan 4 pegawai swasta. Hasil perhitungan probabilitas menunjukan semakin bertambah usia responden maka probabilitasnya mengalami mengalami penurunan dengan semakin bertambahnya umur seseorang maka akan cenderung lebih memilih menggunakan kendaraan pribadi karena lebih mudah mobilitasnya, lebih aman, dan lebih cepat dibandingkan dengan mereka yang usia muda akan lebih banyak memilih menggunakan angkutan umum untuk mobilitasnya karena lebih terjangkau serta lebih murah. Begitupula dengan pekerjaan, para pelajar/mahasiswa probabilitasnya lebih tinggi dibandingkan Pegawai swasta maupun BUMN karena intensitas mobilitas nya tidak sesering Pegawai swasta maupun BUMN.
\end{abstract}

Kata Kunci: Probabilitas, Moda Shift Model, Binary Logit.

\section{ABSTRACT}

Starting December 1, 2019, the Adi Soemarmo Solo Airport Train operates on the route Solo Balapan Station-Adi Soemarmo Airport, with a distance of 12.9 kilometers, and an average travel time of 20 minutes. The mobility of the movements can lead to the mode selection process. Mode selection is one of the models used in planning public transport transportation. The results of the calculation of the probability of displacement for the variable age and occupation of the respondent are variables that have a significant effect. After the final analysis was carried out with categorization for each variable age and occupation, the categories for each age (2) were obtained, namely 21-30 years old and age (3), namely 31-40 years old. For each category of significant work variables, namely the work of 1 student, the occupation of 3 BUMN, and the occupation of 4 private employees. The results of the probability calculation show that the older the respondent is, the probability has decreased as a person gets older, they will tend to prefer to use private vehicles because they are easier to move, safer, and faster than those who are younger and prefer to use public transportation. for mobility because it is more affordable and cheaper. Likewise with work, students / students have a higher probability than private and BUMN employees because their mobility intensity is not as frequent as private employees or BUMN.

Keywords: Probability, Moda Shift Model, Binary Logit. 


\section{PENDAHULUAN}

Keberadaan Bandara Adi Soemarmo Solo memberikan banyak manfaat, Salah satu daerah yang memperoleh manfaat tersebut adalah kota Solo. Pengembangan jaringan dan layanan kereta api bandara (kota menuju bandara) bandara Adi Soemarmo Solo dalam Rencana Induk Perkeretaapian Nasional merupakan program utama pengembangan jaringan dan layanan perkeretaapian tahap II tahun 2016-2020 (RIPnas, 2018) [10]. Mulai 1 Desember 2019. Kereta Api Bandara Adi Soemarmo Solo beroperasi dengan rute Stasiun Solo Balapan-Bandara Adi Soemarmo, dengan jarak sejauh 12,9 kilometer, dan rata-rata waktu tempuh selama 20 menit. Satu rangkaian KA Bandara ini terdiri dari 4 gerbong dengan kapasitas 206 tempat duduk. KA Bandara ini juga dilengkapi dengan kursi khusus penyandang disabilitas dilengkapi pengikat kursi roda. Kereta Bandara Adi Soemarmo merupakan angkutan alternatif dari dan menuju Bandara Adi Soemarmo. Total perjalanan KA Bandara adalah 60 trip sehari, yakni 30 trip ke Bandara Adi Soemarmo dan 30 trip ke Stasiun Balapan Solo. Dengan adanya pelayanan perjalanan angkutan umum yang semakin meningkat nantinya penumpang akan lebih memilih menggunakan angkutan umum dalam melakukan perjalanan sehingga mengurangi beban jalan [1].

Suatu pergerakan dalam dan antar kota faktor pemilihan moda memegang peran yang cukup penting [4]. Banyak pilihan moda transportasi yang dapat digunakan untuk menuju dan dari Bandara Adi Soemarmo. Kendaraan yang digunakan oleh masyarakat saat ini untuk menuju dan dari Bandara Adi Soemarmo masih didominasi oleh kendaraan pribadi yaitu sepeda motor dan mobil. Dengan melihat kecenderungan masyarakat dalam memilih moda maka dapat dibuat suatu model peralihan moda transportasi dari kendaraan pribadi ke kereta api bandara Adi Soemarmo. Untuk mengetahui kinerja variabel-variabel yang memungkinkan adanya perpindahan moda transportasi maka dibuatlah suatu model transportasi, dimana model ini merupakan suatu rencana penyederhanaan dari realita objek atau situasi dari keadaan sebenarnya. Pemilihan moda merupakan salah satu model yang digunakan dalam perecanaan transportasi [3].

Transportasi merupakan katalisator dalam mendukung perekonomian, pertumbuhan sosial dan pengembangan wilayah. Dengan adanya KA Bandara diharapkan semakin mempermudah mobilitas penumpang menjadi lebih cepat. Hasil dari penelitian ini diharapkan dapat mendorong masyarakat untuk menggunakan angkutan masal kereta bandara dalam melakukan mobilitasnya menuju dan dari Bandara Adi Soemarmo.

\section{METODE PENELITIAN}

Penelitian ini termasuk dalam analisis data deskriptif kuantitatif [9]. Sampel dipilih secara acak (random sampel) dimana sampel merupakan responden yang pernah naik pesawat ataupun turun pesawat melalui Bandara Adi Soemarmo Solo. Pengumpulan data dilakukan melalui penyebaran kuesioner melalui sosial media dikarenakan pengumpulan data secara langsung dengan interview maupun wawancara terstruktur tidak memungkinkan ditengah kondisi pandemi covid19.

Metode yang digunakan dalam penelitian ini meliputi penyebaran kuisoner dengan menggunakan google form. Terlebih dahulu dilakukan uji validitas untuk mengetahui keakuratan instrumen. Kemudian dilakukan uji reliabilitas instrumen sehingga dapat diketahui apakah setiap butir pertanyaan tersebut konsisten sehingga dapat digunakan sebagai sebuah alat ukur.

Sebelum melakukan analisis dilakukan pengujian hubungan antara perilaku dalam perpindahan moda dengan variabel karakteristik responden yang mempengaruhi. Analisa probabilitas antara perilaku dalam perpindahan moda dengan variabel yang mempengaruhi dilakukan dengan beberapa skenario analisis regresi logistik biner untuk menganalisa perpindahan moda dari kendaraan pribadi dan angkutan umum ke kereta api bandara [2]. Analisis data model pemilihan moda menggunakan model logit biner dan estimasi parameter model dengan menggunakan analisa regresi [5], [6], [7].

\section{HASIL PEMBAHASAN}

\subsection{Uji Validitas dan Uji Reliabilitas Instrumen}

Instrumen terdiri atas 6 variabel karakteristik pertanyaan responden. Untuk mengetahui apakah perbedaan itu signifikan atau tidak, maka harga $r$ hitung tersebut perlu dibandingkan dengan harga $r$ tabel. Bila $r$ hitung $>r$ tabel, maka perbedaan itu signifikan, sehingga sampel dinyatakan valid.

Hasil perhitungan uji validitas karakteristik responden untuk variabel jenis kelamin dan pendidikan terakhir tidak valid dimana nilai $r$ 
hitung < rtabel sehingga variabel tersebut tidak digunakan untuk perhitungan lebih lanjut. Variabel jenis kelamin $\mathrm{r}$ hitung $0,199<\mathrm{r}$ tabel 0,306 dan variabel pendidikan terakhirr hitung $0,272<\mathrm{r}$ tabel 0,306 . Variabel yang digunakan yaitu variabel usia, variabel pekerjaan, variabel penghasilan, dan variabel tujuan dimana nilai $r$ hitung $>r$ tabel.

Tabel 1. Hasil Uji Validitas Karakteristik Responden

\begin{tabular}{clccc}
\hline No & \multicolumn{1}{c}{ Variabel } & r Hitung & r Tabel & Keterangan \\
\hline 1 & Jenis Kelamin & 0.199 & 0.306 & Tidak Valid \\
2 & Usia & 0.705 & 0.306 & Valid \\
3 & Pendidikan & 0.272 & 0.306 & Tidak Valid \\
& Terakhir & 0.799 & 0.306 & Valid \\
4 & Pekerjaan & 0.589 & 0.306 & Valid \\
5 & Penghasilan & 0.327 & 0.306 & Valid \\
6 & Tujuan & & & \\
\hline
\end{tabular}

Pengujian reliabilitas instrumen dilakukan dengan internal consistency yang dianalisis dengan rumus spearman brown. Uji reliabilitas mengacu pada konsistensi atau keterpercayaan hasil ukur yang mengandung makna kecermatan pengukuran. Reliabilitas merupakan penilaian tingkat konsistensi terhadap hasil pengukuran bila dilakukan beberapa pengukuran pada sebuah variabel. Pengukuran yang tidak reliabel akan menghasilkan skor yang tidak dapat dipercaya. Pengukuran ini menggunakan teknik $\alpha$ conbach, koefisien $\alpha$ ini bernilai 0-1, semakin tinggi koefisiennya maka semakin mendekati baik. Bila nilai Cronbach's Alpha > 0,6 maka dapat dinyatakan reliabel. Bila nilai Cronbach's Alpha $<0,6$ maka dapat dinyatakan tidak reliabel.

Tabel 2 Hasil Uji Reliabilitas Karakteristik Responden

\begin{tabular}{rr}
\hline \multicolumn{2}{c}{ Reliability Statistics } \\
\hline Cronbach's Alpha & N of Items \\
.635 & 6 \\
\hline
\end{tabular}

Berdasarkan hasil perhitungan pada Tabel 6 mengenai nilai uji reliabilitas diperoleh nilai hitung 0,635>0,6 maka dapat disimpulkan instrumen dapat dinyatakan reliabel dan dapat digunakan untuk uji yang selanjutnya.

\subsection{Probabilitas Perpindahan Moda}

Dari hasil kuisoner diketahui seberapa besar peluang untuk berpindah moda ke kereta api bandara Adi Soemarmo Solo. Dari analisa karakteristik diperoleh jumlah proporsi karakteristik responden berdasarkan variabel yang ada pada formulir kuisoner. Variabel tersebut kemudian dilakukan uji secara bersamaan berdasarkan probabilitas perpindahan dan berdasarkan tarif yang diharapkan. Karakteristik yang mempengaruhi responden dalam menentukan pilihan menggunakan moda kereta api bandara Adi Soemarmo Solo, angka signifikan $<\operatorname{sig}<\alpha$, dimana $\alpha$ adalah nilai toeransi kesalahan penguji yang diujikan. Dalam analisa ini nilai $\alpha$ adalah 5\%.

Penetapan harga tiket turut menentukan laku tidaknya angkutan umum tersebut. Ada dua tahap dalam penentapan harga, yaitu pertama, menyangkut waktu produksi dan konsumsi jasa-jasa angkutan. Kedua, menyangkut tempat atau lokasi dimana alat-alat produksi angkutan berhenti dan muatan membutuhkan jasa-jasa angkutan. Parameter yang dinilai mampu untuk menggambarkan kemampuan membayar tiket angkutan umum diantaranya $\mathrm{Kg}-\mathrm{km}$ per rupiah biaya operasi, Revenue per rupiah biaya operasi, Revenue pertenaga kerja yang terlibat. Penentuan tarif juga berdasarkan kemampuan membayar masyarakat suatu daerah dilihat dari PDRB dan perekonomian. Harga tiket yang berlaku untuk sekarang ini kereta api bandara Adi Soemarmo Solo adalah Rp 15.000. Jadi fasilitas yang ditawarkan ke pengguna kendaraan pribadi sangat ditentukan terhadap harga tiket dan fasilitas yang didapatkan oleh pengguna moda. Kemauan berpindah didasari karena ada penambahan fasilitas kereta api bandara Adi Soemarmo Solo yang ditawarkan seperti pada tabel berikut.

Tabel 3. Fasilitas Yang Ditawarkan Kemauan Berpindah

\begin{tabular}{cl}
\hline No & \multicolumn{1}{c}{ Fasilitas yang di peroleh } \\
\hline 1 & Rute Klaten-Solo Balapan-Bandara Adi Soemarmo \\
2 & Waktu tempuh 19 menit hingga 1 jam 11 menit \\
3 & $\begin{array}{l}\text { Pelayanan : AC, CCTV, Toilet, Tempat duduk yang } \\
\text { nyaman, Armada Baru }\end{array}$ \\
4 & $\begin{array}{l}\text { Frekuensi perjalanan 34 kali perjalanan pergi- } \\
\text { pulang sehari }\end{array}$ \\
5 & Kecepatan operasional 40-90 km/jam \\
6 & Tarif Rp 15.000 \\
\hline
\end{tabular}

\subsection{Karakteristik Responden}

Penentuan karakteristik pertanyaan variabel dalam penelitian ini terbagi dalam beberapa kategori yaitu jenis kelamin, usia, pendidikan terakhir, pekerjaan, penghasilan, dan tujuan. Penelitian ini menggunakan sampel sebanyak 100 responden. Responden merupakan penumpang/pengguna jasa pesawat terbang di bandara Adi Soemarmo Solo baik yang menggunakan kendaraan pribadi (mobil dan sepeda motor)/kereta bandara/bus damri/ojek online/taksi maupun kendaraan hotel/travel agen untuk perpindahan modanya. Berdasarkan data yang 
diperoleh karakteristik responden secara umum sebagai berikut:

1. Distribusi jenis kelamin responden

Dari jumlah keseluruhan sampel yang diperoleh sebanyak 100 respondem diketahui distribusi jenis kelamin jumlah responden laki-laki sebanyak $60 \%$ dan $40 \%$ adalah perempuan. Distribusi jenis kelamin responden dapat dilihat pada Gambar 1.

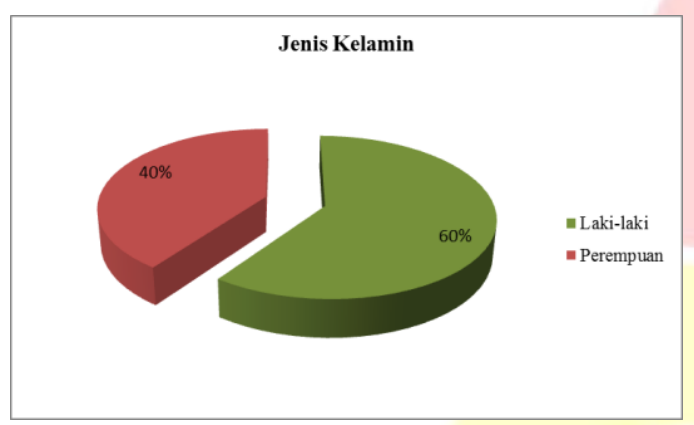

Gambar 1 Karakteristik Responden Berdasarkan Jenis Kelamin

2. Distribusi usia responden

Distribusi usia responden dapat dilihat pada Gambar 2. Dari segi usia responden di dalam penelitian ini relatif bervariasi. Karakteristik usia didapatkan responden dengan usia $<20$ tahun sebanyak $17 \%$, usia 21-30 tahun mendominasi yaitu sebesar $57 \%$, usia 3140 tahun sebesar 7\%, usia 41-50tahun sebesar 8\%, dan usia $>50$ tahun sebesar $11 \%$.

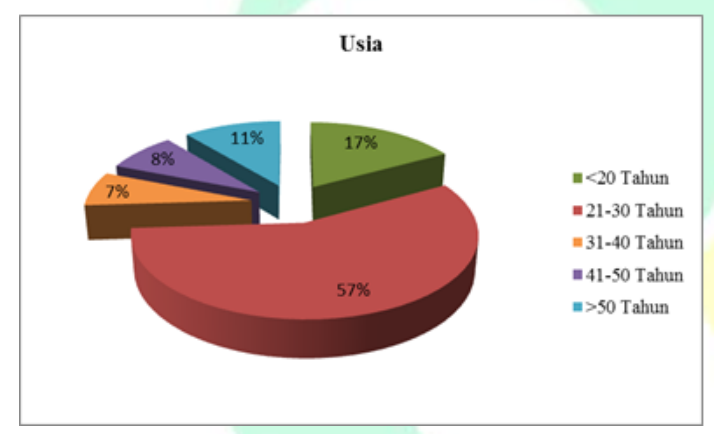

Gambar 2 Karakteristik Responden Berdasarkan Usia

3. Distribusi Pendidikan Terakhir Responden

Karakteristik pendidikan terakhir responden diketahui sebesar $35 \%$ dengan pendidikan terakhir SMA, 14\% dengan pendidikan terakhir D1/D2/D3, sedangkan pendidikan terakhir D4/S1 sebesar $28 \%$, untuk pendidikan terakhir S2/S3 sebesar $23 \%$. Responden terbanyak memiliki jenjang pendidikan SMA dimana pendidikan secara langsung maupun tidak dapat mempengaruhi pola pikir dan kecenderungan dalam menghadapi pilihan. Distribusi pendidikan terakhir responden dapat dilihat pada Gambar 3.

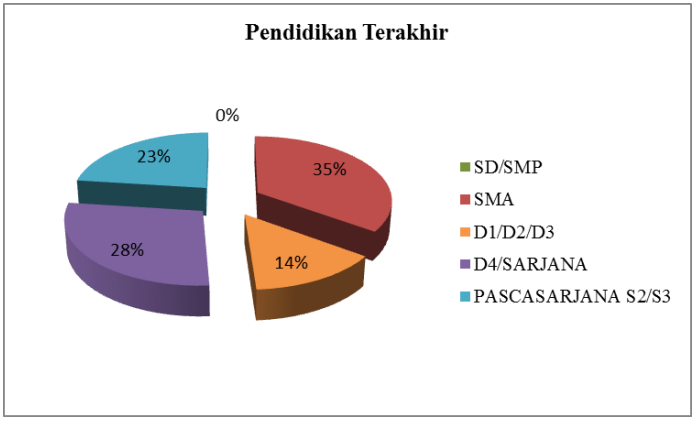

Gambar 3 Karakteristik Responden Berdasarkan Pendidikan Terakhir

4. Distribusi Pekerjaan Responden

Sebanyak 23\% responden bekerja sebagai pegawai swasta, $6 \%$ bekerja sebagai wiraswasta/pengusaha, $3 \%$ sebagai BUMN, sebesar $19 \%$ bekerja sebagai PNS/TNI/Polri, 28\% sebagai pelajar/mahasiswa, dan lainnya (ibu rumah tangga, petani, pensiunan, dll) sebesar $21 \%$.

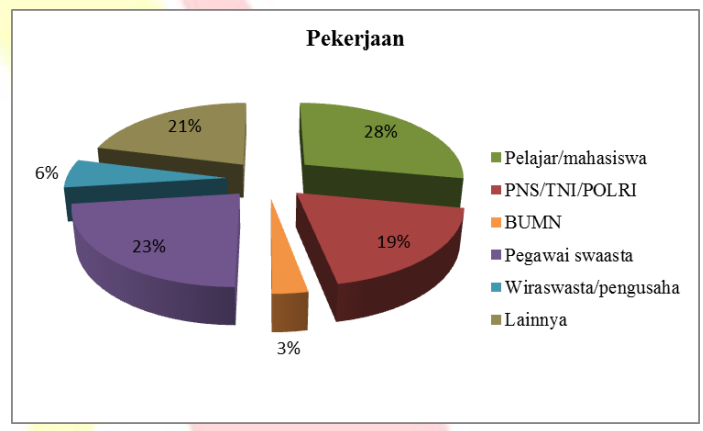

Gambar 4 Karakteristik Responden Berdasarkan Pekerjaan

5. Distribusi Penghasilan Responden

Penghasilan responden diketahui sebanyak 30\% pendapatan responden sebesar Rp 3 juta - Rp 6 juta, $11 \%$ responden penghasilan perbulannya sebesar Rp 6 juta - Rp 9 juta, responden yang berpenghasilan $>$ Rp 9 juta sebanyak $2 \%$, sebanyak $28 \%$ penghasilan perbulannya sebesar < Rp 3 juta, dan sisanya 29\% belum berpenghasilan. Distribusi pendapatan responden dapat dilihat pada Gambar 5.

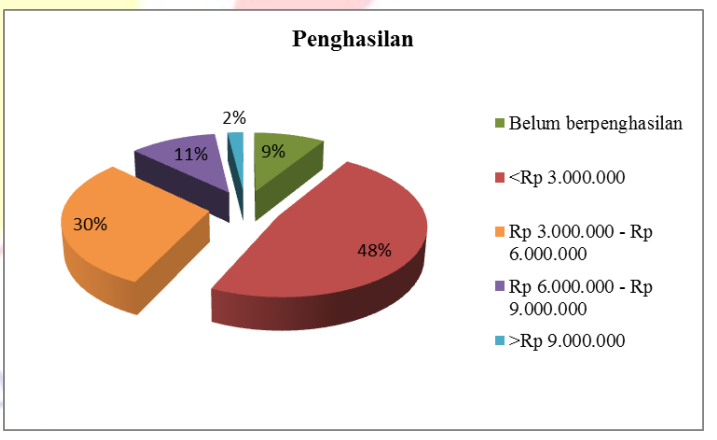

Gambar 5 Karakteristik Responden Berdasarkan Penghasilan 


\section{Distribusi Keperluan Atau Tujuan Berpergian}

Distribusi keperluan atau tujuan perjalanan responden diketahui sebanyak $37 \%$ responden dengan maksud tujuan mengunjungi keluarga, 7\% dengan maksud perjalanan kuliah/sekolah, sebesar $10 \%$ dengan maksud perjalanan rekreasi/liburan, sebesar 4\% dengan maksud perjalanan urusan bisnis, sebesar 33\% dengan maksud tujuan perjalanan dinas, dan sisanya 9\% dengan maksud perjalanan lainnya (berobat/kontrol kesehatan/bertemu dokter, dalam rangka lomba/pertandingan club antar kota, umroh, dll). Distribusi maksud perjalanan responden dapat dilihat pada Gambar 6 .

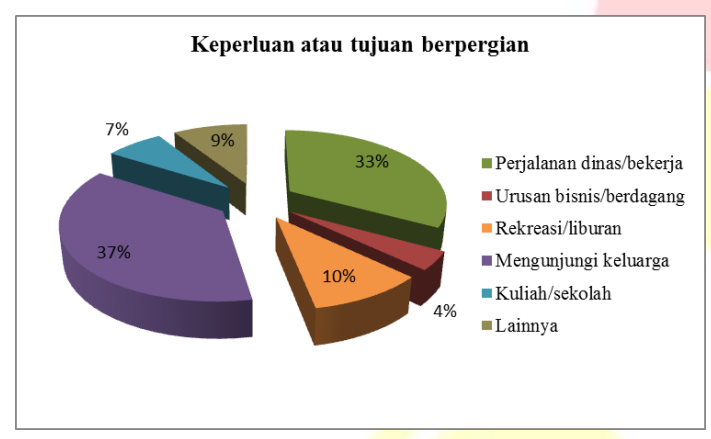

Gambar 6 Karakteristik Responden Berdasarkan Keperluan Atau Tujuan Berpergian

7. Distribusi Kendaraan Yang Digunakan Dari Dan Menuju Bandara Adi Soemarmo

Distribusi Kendaraan Yang Digunakan Dari Dan Menuju Bandara Adi Soemarmo responden diketahui sebanyak $40 \%$ responden menggunakan kendaraan pribadi, $4 \%$ menggunakan bus damri, sebesar $18 \%$ menggunakan kereta bandara adi soemarmo, sebesar $4 \%$ menggunakan taksi, sebesar $22 \%$ menggunakan ojek online baik sepeda motor maupun mobil, dan sisanya $12 \%$ menggunakan kendaraan sewa/travel/fasilitas hotel/kendaraan kantor. Distribusi Kendaraan Yang Digunakan Dari Dan Menuju Bandara Adi Soemarmo dapat dilihat pada Gambar 7.

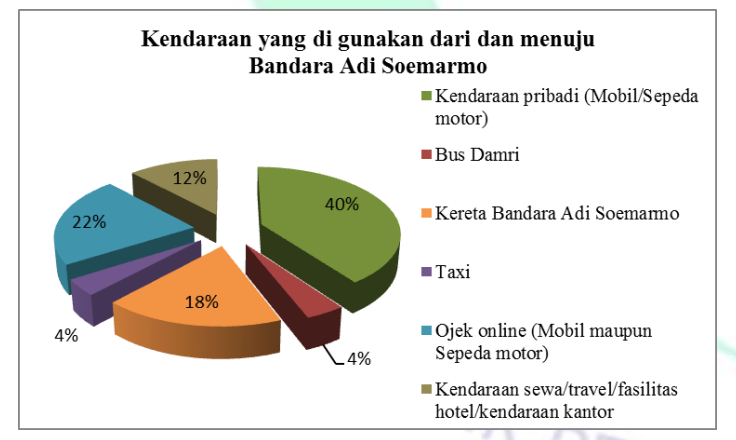

Gambar 7 Karakteristik Responden Berdasarkan Kendaraan Yang Digunakan Dari Dan Menuju Bandara Adi Soemarmo

\subsection{Hubungan Antara Perilaku Dalam Perpindahan Moda Dengan Variabel- variabel Yang Mempengaruhi}

Dalam analisis ini digunakan chi square untuk mengetahui hubungan antara masing masing variabel bebas dengan perilaku penumpang untuk berpindah moda ke kereta api bandara Adi Soemarmo Solo [8]. Hasil dari uji hubungan ditabelkan pada pada Tabel 4. hasil uji chi-square antara hubungan variabel bebas (karakteristik responden).

Tabel 4 Hasil Uji Chi Square Antara Hubungan Variabel Bebas Karakteristik Responden

\begin{tabular}{llccccc}
\hline No & $\begin{array}{c}\text { Variabel } \\
\text { Bebas }\end{array}$ & Df & $\begin{array}{c}\text { Chi } \\
\text { Square }\end{array}$ & $\begin{array}{c}\text { Chi } \\
\text { Square } \\
\text { Tabel }\end{array}$ & Signifikan & Keputuasan \\
\hline 1 & Usia & 4 & 16.447 & 7.779 & 0.002 & Ho Tolak \\
2 & Pekerjaan & 5 & 14.517 & 9.236 & 0.013 & Ho Tolak \\
3 & Penghasilan & 4 & 10.167 & 7.779 & 0.038 & Ho Tolak \\
4 & Tujuan & 5 & 4.827 & 9.236 & 0.437 & Ho Terima \\
\hline
\end{tabular}

Hasil analisis uji chi-square tersebut bisa diambil kesimpulan yaitu chi kuadrat hasil perhitungan > chi square tabel maka H0 ditolak, atau dari level of significant hitung $<$ level of significant $(\alpha) 0.1$ maka Ho ditolak. Dapat disimpulkan ada hubungan yang signifikan antara variabel yang diuji. Atau bisa juga dikatakan variabel kemauan berpindah berpengaruh signifikan terhadap variabel usia, pekerjaan, dan penghasilan.

\subsection{Analisa Probabilitas Antara Perilaku Dalam Perpindahan Moda Dengan Variabel- variabel Yang Mempengaruhi}

Berdasarkan variabel usia, pekerjaan, dan penghasilan dengan regresi logistik, dilakukan uji wald. Uji wald digunakan untuk uji nyata parsial bagi koefisien variabel. Signifikan untuk uji wald adalah kurang dari 0.1. Kriteria uji: tolak H0 jika nilai walad $>$ nilai $\mathrm{X}^{2} 0.1$ atau nilai sig $<\alpha$, dengan taraf signifikansi $\alpha=10 \%$.

Tabel 5 Hasil Uji Wald Variabel Usia, Pekerjaan, Dan Penghasilan

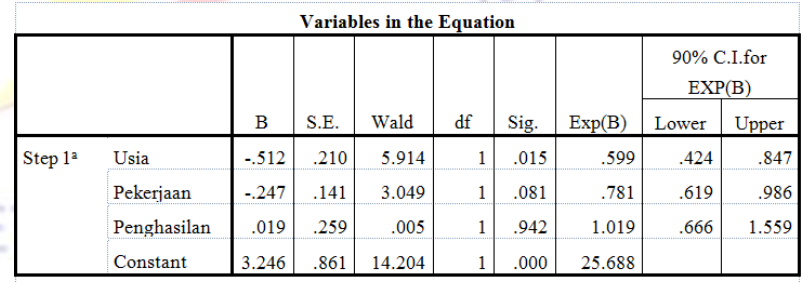

a. Variable(s) entered on step 1: Usia, Pekeriaan, Penghasilan 
Berdasarkan Tabel 5 dapat disimpulkan bahwa terdapat 2 variabel bebas yang berpengaruh signifikan yaitu usia responden dan pekerjaan responden. Oleh sebab itu untuk variabel penghasilan dieliminasi dan tidak diikutsertakan pada analisis selanjutnya karena tidak berpengaruh secara signifikan terhadap perilaku pemilihan moda.

Setelah dilakukan uji signifikansi terhadap model maka diperoleh hasil bahwa variabel yang berpengaruh signifikan terhadap perilaku pemilihan moda yaitu variabel usia responden dan pekerjaan responden. Selanjutnya dari variabel yang berpengaruh signifikan tersebut dilakukan analisis kembali dengan pengkategorian tiap variabel. Berikut analisis model regrei logistik biner untuk kategori variabel dengan tidak mengikutsertakan variabel yang tidak berpengaruh signifikan.

Tabel 6 Nilai Penduga Parameter, Statistik Uji Wald, Dan Odds Ratio

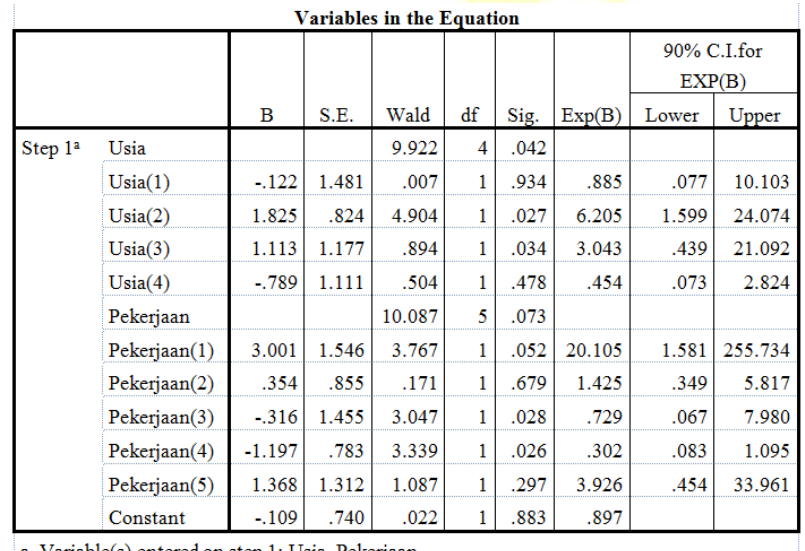

a. Variable(s) entered on step 1: Usia, Pekerjaan.

Berdasarkan Tabel 6 diatas dapat dilihat bahwa usia (2), usia (3), pekerjaan (1), pekerjaan (3), dan pekerjaan (4), berpengaruh signifikan terhadap variabel respon/tidak bebas. Untuk usia (2) range usia 21-30 tahun, usia (3) range usia 31-40 tahun, pekerjaan (1) pelajar/mahasiswa, pekerjaan (3) BUMN, pekerjaan (4) pegawai swasta. Dari hasil tersebut didapatkan beberapa persamaan logit perpindahan moda yaitu sebagai berikut:

1) Persamaan logit perpindahan moda untuk usia (2) range usia 21-30 tahun dan pekerjaan (1) pelajar/mahasiswa didapatkan persamaan

$$
\begin{aligned}
\operatorname{Logit}(p) & =\ln \frac{p}{1-p} \\
& =\beta 0 \pm \mathrm{k} \mathrm{Xk} \\
& =-0,109+1,825 \text { Usia2 }+3,001 \text { Pekerjaan }
\end{aligned}
$$

Hasil dari persamaan logit tersebut kemudian dimasukan ke dalam rumus perhitungan probabilitas.
$\mathrm{P}$

exp $p^{\operatorname{logit}(p)}$

$\frac{\exp }{1+\exp ^{\log i t(p)}}$

(2)

Tabel 7 Nilai Probabilitas Untuk Usia (2) Dan Pekerjaan (1)

\begin{tabular}{cccc}
\hline Usia 2 & Pekerjaan 1 & Logit $(\mathrm{p})$ & $\mathrm{P}(\%)$ \\
\hline 21 & Pelajar/Mahasiswa & 2.979 & 95.16 \\
22 & Pelajar/Mahasiswa & 2.975 & 95.14 \\
23 & Pelajar/Mahasiswa & 2.971 & 95.12 \\
24 & Pelajar/Mahasiswa & 2.968 & 95.11 \\
25 & Pelajar/Mahasiswa & 2.965 & 95.10 \\
26 & Pelajar/Mahasiswa & 2.962 & 95.08 \\
27 & Pelajar/Mahasiswa & 2.960 & 95.07 \\
28 & Pelajar/Mahasiswa & 2.957 & 95.06 \\
29 & Pelajar/Mahasiswa & 2.955 & 95.05 \\
30 & Pelajar/Mahasiswa & 2.953 & 95.04 \\
\hline
\end{tabular}

2) Persamaan logit perpindahan moda untuk usia (2) range usia 21-30 tahun dan pekerjaan (3) BUMN didapatkan persamaan

$\operatorname{Logit}(p)=$ $\ln \frac{p}{1-p}$

$$
\begin{aligned}
& =\beta 0 \pm \mathrm{kXk} \\
& =-0,109+1,825 \text { Usia2 }-0,316 \text { Pekerjan3 }
\end{aligned}
$$

Hasil dari persamaan logit tersebut kemudian dimasukan ke dalam rumus perhitungan probabilitas

$\mathrm{P}=\frac{\exp ^{\log i t(p)}}{1+\exp ^{\log i t(p)}}$

Tabel 8 Nilai Probabilitas Untuk Usia (2) Dan Pekerjaan (3)

\begin{tabular}{cccc}
\hline Usia 2 & Pekerjaan 3 & Logit $(\mathrm{p})$ & $\mathrm{P}(\%)$ \\
\hline 21 & BUMN & -0.338 & 41.63 \\
22 & BUMN & -0.342 & 41.53 \\
23 & BUMN & -0.346 & 41.44 \\
24 & BUMN & -0.349 & 41.36 \\
25 & BUMN & -0.352 & 41.29 \\
26 & BUMN & -0.355 & 41.22 \\
27 & BUMN & -0.357 & 41.16 \\
28 & BUMN & -0.360 & 41.10 \\
29 & BUMN & -0.362 & 41.05 \\
30 & BUMN & -0.364 & 41.00 \\
\hline
\end{tabular}


3) Persamaan logit perpindahan moda untuk usia (2) range usia 21-30 tahun dan pekerjaan (4) Pegawai swasta didapatkan persamaan

$$
\operatorname{Logit}(p)=\ln \frac{p}{1-p}
$$

)

$$
\begin{aligned}
& =\beta 0 \pm \mathrm{k} \mathrm{Xk} \\
& =-0,109+1,825 \text { Usia } 2-1,197 \text { Pekerjaan } 4
\end{aligned}
$$

Hasil dari persamaan logit tersebut kemudian dimasukan ke dalam rumus perhitungan probabilitas

$\mathrm{P}=\frac{\exp ^{\log i t(p)}}{1+\exp ^{\log i t(p)}}$

Tabel 9 Nilai Probabilitas Untuk Usia (2) Dan Pekerjaan (4)

\begin{tabular}{cccc}
\hline Usia 2 & Pekerjaan 4 & Logit $(\mathrm{p})$ & $\mathrm{P}(\%)$ \\
\hline 21 & Pegawai Swasta & -1.219 & 22.81 \\
22 & Pegawai Swasta & -1.223 & 22.74 \\
23 & Pegawai Swasta & -1.227 & 22.68 \\
24 & Pegawai Swasta & -1.230 & 22.62 \\
25 & Pegawai Swasta & -1.233 & 22.57 \\
26 & Pegawai Swasta & -1.236 & 22.52 \\
27 & Pegawai Swasta & -1.238 & 22.47 \\
28 & Pegawai Swasta & -1.241 & 22.43 \\
29 & Pegawai Swasta & -1.243 & 22.39 \\
30 & Pegawai Swasta & -1.245 & 22.36 \\
\hline
\end{tabular}

4) Persamaan logit perpindahan moda untuk usia (3) range usia 31-40 tahun dan pekerjaan (3) BUMN didapatkan persamaan

$\operatorname{Logit}(p)=\ln \frac{p}{1-p}$

$$
\begin{aligned}
& =\beta 0 \pm \mathrm{k} \mathrm{Xk} \\
& =-0,109+1,113_{\text {Usia3 }}-0,316_{\text {Pekerjaan3 }}
\end{aligned}
$$

Hasil dari persamaan logit tersebut kemudian dimasukan ke dalam rumus perhitungan probabilitas $\mathrm{P}=\frac{\exp ^{\log i t(p)}}{1+\exp ^{\log i t(p)}}$

(2)

Tabel 9 Nilai Probabilitas Untuk Usia (3) Dan Pekerjaan (3)

\begin{tabular}{cccc}
\hline Usia 3 & Pekerjaan 3 & Logit $(\mathrm{p})$ & $\mathrm{P}(\%)$ \\
\hline 31 & BUMN & -0.389 & 40.39 \\
32 & BUMN & -0.390 & 40.37 \\
33 & BUMN & -0.391 & 40.34
\end{tabular}

\begin{tabular}{cccc}
\hline Usia 3 & Pekerjaan 3 & Logit $(\mathrm{p})$ & $\mathrm{P}(\%)$ \\
\hline 34 & BUMN & -0.392 & 40.32 \\
35 & BUMN & -0.393 & 40.30 \\
36 & BUMN & -0.394 & 40.27 \\
37 & BUMN & -0.395 & 40.25 \\
38 & BUMN & -0.396 & 40.24 \\
39 & BUMN & -0.396 & 40.22 \\
40 & BUMN & -0.397 & 40.20 \\
\hline
\end{tabular}

5) Persamaan logit perpindahan moda untuk usia (3) range usia 31-40 tahun dan pekerjaan (4) Pegawai swasta didapatkan persamaan

$$
\begin{aligned}
\operatorname{Logit}(p) & =\ln \frac{p}{1-p} \\
& =\beta 0 \pm \mathrm{k} \mathrm{Xk} \\
& =-0,109+1,113 \text { Usia3 }-1,197 \text { Pekerjaan4 }
\end{aligned}
$$

Hasil dari persamaan logit tersebut kemudian dimasukan ke dalam rumus perhitungan probabilitas

$\mathrm{P}=\frac{\exp ^{\log i t}(p)}{1+\exp ^{\log i t(p)}}$

Tabel 10 Nilai Probabilitas Untuk Usia (3) Dan Pekerjaan (4)

\begin{tabular}{cccc}
\hline Usia 3 & Pekerjaan 4 & Logit (p) & P (\%) \\
\hline 31 & Pegawai Swasta & -1.270 & 21.93 \\
32 & Pegawai Swasta & -1.271 & 21.91 \\
33 & Pegawai Swasta & -1.272 & 21.89 \\
34 & Pegawai Swasta & -1.273 & 21.87 \\
35 & Pegawai Swasta & -1.274 & 21.86 \\
36 & Pegawai Swasta & -1.275 & 21.84 \\
37 & Pegawai Swasta & -1.276 & 21.83 \\
38 & Pegawai Swasta & -1.277 & 21.81 \\
39 & Pegawai Swasta & -1.277 & 21.80 \\
40 & Pegawai Swasta & -1.278 & 21.79 \\
\hline
\end{tabular}

Sebelum model dinyatakan layak, model tersebut harus diuji statistik. Pengujian model regresi logistik biner menggunakan uji hosmer and lemeshow test, dengan asumsi:

Ho : Model tidak cukup mampu menjelaskan data

H1 : Model telah cukup mampu menjelaskan data/sesuai

Terima Ho jika sig < 0,1

Tabel 11 Nilai Hosmer And Lemeshow Test

\begin{tabular}{cccc}
\hline \multicolumn{4}{c}{ Hosmer and Lemeshow Test } \\
\hline Step & Chi-square & df & Sig. \\
\hline
\end{tabular}




\begin{tabular}{llll}
\hline 1 & 2.024 & 6 & .917 \\
\hline
\end{tabular}

Pada tabel 11 diatas menyatakan bahwa hasil nilai sig. sebesar 0,917>0,1 sehingga Ho ditolak, model telah cukup mampu menjelaskan data/sesuai dan dapat disimpulkan bahwa model variabel mempengaruhi perpindahan moda.

\section{KESIMPULAN}

Hasil perhitungan probabilitas menunjukan semakin bertambah usia responden maka probabilitasnya mengalami mengalami penurunan dengan semakin bertambahnya umur seseorang maka akan cenderung lebih memilih menggunakan kendaraan pribadi karena lebih mudah mobilitasnya, lebih aman, dan lebih cepat dibandingkan dengan mereka yang usia muda akan lebih banyak memilih angkutan umum untuk mobilitasnya karena lebih terjangkau lebih murah. Untuk pengkategorian kemungkinan tiap variabel terlalu luas atau kemungkinan sampel terlalu sedikit. Begitupula dengan pekerjaan, para pelajar/mahasiswa probabilitasnya lebih tinggi dibandingkan Pegawai swasta maupun BUMN karena intensitas mobilitas nya tidak sesering Pegawai swasta maupun BUMN.

\section{DAFTAR PUSTAKA}

[1] Leliana, Arinda., Widyastuti, Hera. (2019), Analisis Perpindahan Moda Dari Sepeda Motor Dan Mobil Pribadi Ke Angkutan Umum Di Stasiun Madiun, Jurnal Aplikasi Teknik Sipil, Volume 17, Nomor 2, Agustus 2019, Surabaya;

[2] Miharti, Isria. M.P. (2019), Analisis Probabilitas Perpindahan Moda Dari Kendaraan Pribadi ke Bus Damri Dan Tranex Mandiri Di Bandara Internasioanl Minangkabau, Jurnal Aplikasi Teknik Sipil, Volume 18, Nomor 1, Februari 2020, Suarabaya;

[3] Tamin, O.Z. (2000), Perencanaan \& Pemodelan Transportasi, Edisi Kedua, Institut Teknologi Bandung, Bandung;

[4] Taufan, Galang Putra. (2017), Analisa Probabilitas Perpindahan PenggunaMobil Pribadi Ke Bus Damri Rute Perjalanan Bandara Adi Sucipto-Kota Magelang, Institut Teknologi Sepuluh Nopember, Surabaya;

[5] Tuames, Gapar Y.K. (2019), Analisis Probabilitas Penumpang Bus Di Dalam Dan Di Luar Terminal Oebobo Berbasis Karakteristik Sosial Ekonomi Dan Aksesibilitas Dengan Metode Relevated Preference, Jurnal Aplikasi Teknik Sipil, Volume 18, Nomor 1, Februari 2020, Suarabaya;
[6] Sari, Ratna S.T. (2019), Analisis Probabilitas Pemilihan Moda Pesawat Terbang Dan Kapal Laut Pada Rute Fakfak Sorong Dengan Metode Revealed Preference, Jurnal Aplikasi Teknik Sipil, Volume 17, Nomor 1, Februari 2020, Suarabaya;

[7] Soimun, Ahmad. (2018), Analisis Probabilitas Perpindahan Moda Pengguna Kendaraan Pribadi (Sepeda Motor Dan Mobil) Ke Kereta Api Commuter Surabaya Sidoarjo, Institut Teknologi Sepuluh Nopember, Surabaya;

[8] Sudjana. (2005), Metoda Statistika edisi 6, Penerbit Tarsito, Bandung;

[9] Sugiyono. (2017), Motode Penelitian Kuantitatif, Kualitatif, dan $R \& D$, Alfabeta, Bandung.

[10] Peraturan Menteri Nomor KP 2128 Tahun 2018 tentang Rencana Induk Perkeretaapian Nasional Kementerian Perhubungan Ditjen Perkeretaapian, Jakarta. 